\title{
MÚSICA
}

\section{Música em 2004}

Há um consenso de que a música está seguindo em uma trajetória marcada pelo abandono de seus antigos suportes físicos e se apropriando de novas formas de disseminação, como a Internet. Com a evolução tecnológica, surgem mudanças substantivas em velhos hábitos de consumo. Neste ensaio, Adriana Baggio, publicitária e colunista do Digestivo Cultural, analisa as principais influências dos meios digitais sobre o relacionamento de empresas, consumidores e artistas com a música.

mãe está em casa, enfurnada no quarto da bagunça, mexendo em caixas que há muito não são abertas. 0 filho chega, tentando descobrir algum segredo que porventura possa estar escondido em meio a tantas coisas velhas. Ela retira uns papéis com imagens, onde o menino reconhece feições familiares. Depois, um velho tel efone ceIular, que o avô guardou por muitos anos. Mas quando a mãe puxa do fundo da caixa outras caixinhas menores, quadradas, o menino fica curioso.

$\mathrm{N}$ a parte da frente de al gumas dessas caixinhas estão imagens de pessoas, em outras apenas formas abstratas. Ele espera que ela abra as caixinhas, mas ela não abre. Fica olhando pensativa para as imagens. Algumas provocam sorrisos, outras um olhar de desprezo. Vai tirando e empilhando cada 
uma no chão ao seu lado. Q uando não agüenta mais de curiosidade, 0 menino pergunta:

- Mãe, o que tem dentro dessas caixinhas?

- CDs, filho.

- Cê-Dê? 0 que é isso?

- É um tipo de disco onde ficam gravadas músicas. A gente coloca esses discos em aparelhos e eles tocam as músicas.

- No seu tempo, as coisas eram bem mais difíceis, né, mãe?

E com essa observação o menino sai do quarto, exasperado como são as crianças com as coisas vel has e obsoletas, sem ter tido a oportunidade de ver os LPs que se acomodavam bem no fundo da caixa de memórias.

\section{Exercíci o de futurologia. Essa} pequena fábula pode se tornar realidade dentro de não muito tempo. Se considerarmos as mudanças da nossa relação com a música, é possível perceber que, no aspecto do suporte, logo, logo estaremos deixando os meios físicos. As músicas virarão bits e nossos filhos não saberão o que é $C D$, assim como, para as crianças de hoje, um LP de vinil é algo totalmente obsoleto. Aparelhos como o iPod, da Apple, arquivam e tocam músicas baixadas da internet. $\mathrm{N}$ ão precisa mais nem ter gravador de CD em casa. A música permanece informação, desde sua execução até seu consumo, sem ter que passar por um suporte físico para ser distribuída, comercializada, armazenada e ouvida. E as novas gerações de aparelhos carregam

\section{Se considerarmos a nossa relação com a música, no quesito}

suporte, é fácil perceber que logo, logo estaremos deixando os meios físicos.

tanta quantidade de dados que talvez as músicas que cabem ali dentro não consigam ser ouvidas durante a vida inteira de alguém - pelo menos com a expectativa de vida atual.

Para os mais jovens, os que têm uma relação mais amigável com a tecnologia, comprar CDs já é al go ultrapassado. Segundo uma pesquisa de julho deste ano, publicada no site Cachelogic.com, são feitos mais de 3 bilhões de downloads de música todos os dias no mundo, a maioria pirata. Mas por que nem todas as gravadoras estão preocupadas com esse movimento, já que mais e mais pessoas baixam músicas da internet e gravam seus próprios CDs em casa, sem comprá-los nas lojas? A resposta é que algumas empresas já perceberam que, assim como outros produtos, o CD é apenas um suporte para música e está virando commodity. Ou seja, hoje em dia, qualquer um pode fazer. Vai se dar melhor nessa briga quem conseguir agregar mais valor ao produto. E qual seria esse valor? Atrelar novas experiências ao consumo da música.

Em fase de adaptação. I niciativas como meios de impedir cópias dos CDs vendidos nas lojas, processos contra os programas de troca de arquivos pela internet e combateà pirataria são medidas que até podem resolver o problema das grandes gravadoras em curto prazo. Mas o preço a ser pago tem sido alto: cada uma dessas ações provoca a antipatia do consumidor de música e faz com que ele procure opções alternativas. 0 cenário tem mostrado que a troca de músicas pela internet veio para ficar. Para se manterem lucrativas nesse negócio, as empresas precisam reinventar a relação com o seu público dentro desse contexto. Por isso, a força não é o melhor método a ser utilizado. Será preciso abandonar a posição confortável das cadeiras de executivo e sair a campo para conhecer o novo consumidor.

Se, por um lado, a internet e as possibilidades de troca de músicas prejudicam as majors, por outro lado representam uma grande oportunidade para os pequenos selos ou artistas que antes não tinham opção para divulgação de suas obras. Da mesma forma, as pessoas que antes dependiam do rádio ou do estoque das lojas agora podem saber o que se faz de novo em termos de música sem levantar da cadeira. A internet permite 0 encontro dos que querem mostrar ao mundo o que fazem, e que nunca passariam da portaria de uma gravadora ou de uma emissora de rádio, com aqueles que estão cansados de ter seus gostos musicais pautados pelos "jabás" dessas mesmas rádios ou 
O cenário tem mostrado que a troca de músicas pela Internet veio para ficar. Para se manterem lucrativas nesse negócio, as empresas precisam reinventar a relação com o seu público.

por algum burocrático setor de compras de uma loja de discos, que só encomenda os $C D s$ mais vendidos.

Admi rável mundo novo. 0 resultado é que, para os artistas alternativos, os downloads ajudam a vender mais ingressos para os show, e, durante a apresentação, também acabam vendendo $C D s$, camisetas e outros produtos que fazem com que o público não apenas assista a um espetáculo, mas viva uma experiência musical. Isso é lógico para os artistas, porque é das apresentações que vêm o grosso do dinheiro. Mesmo para os cantores e bandas mais famosos, a participação nas vendas de CDs é pequena. 0 lucro maior fica, é evidente, para as gravadoras.

Entre a crise das majors e a oportunidade dos pequenos selos, está o caso Trama. A gravadora reúne artistas conhecidos, de qualidade, mas nem chega aos pés das grandes em termos de faturamento. No entanto, talvez por estar no meio do caminho, pode experimentar novas alternativas para se dar bem nesse cenário. Com o projeto TramaVirtual.com.br, a gravadora incentiva a troca de músicas pela internet, tanto no seu próprio site como em blitze realizadas por outros locais da rede, premiando os usuários que estiverem baixando músicas dos seus artistas. No TramaVirtual, qualquer banda ou artista pode ter uma página para divulgar o seu trabalho e ainda liberar músicas próprias em MP3 para serem baixadas pel os internautas. Estes, por sua vez, podem participar de fóruns e fazer resenhas sobre as bandas e músicos. Mais uma vez, é a experiência com a música que tem atraído o público.

Mas não são apenas artistas ou projetos desconhecidos que podem ser obtidos de graça pelo site. A Trama está disponibilizando, até o final do ano, o download gratuito do CD 3.2, de Jair Oliveira. 03.2 reúne músicas gravadas durante a produção do 3.1, mas que não couberam nessa versão. São 8 músicas que o internauta pode baixar em arquivo compactado para Windows ou Mac, além da capa e do encarte do CD em PDF. 0 fato de disponibilizar também a parte impressa que acompanha a embalagem de um CD comprado em loja mostra a preocupação da Trama em agregar valor ao seu produto. Talvez por fazer parte de uma parcela de público mais obsoleta, uma das coisas que mais me incomodam em um $C D$ gravado em casa é a falta de atratividade da embalagem sem capa nem encarte. O bter a essência de tudo faz parte da dinâmica da cultura da geração atual, que parece viver em uma eterna gincana para saber quem conhece ou consome mais entre as infinitas possibilidades de informação que são oferecidas todo momento. Nesse contexto, o que é uma capa, um encarte? Para esse público, nada. Mas para quem busca mais do que apenas consumir, representa a experiência que tem feito com que as pessoas optem por uma determinada marca em detrimento de outra.

Consenso. A troca de música pela internet - seja paga ou gratuita veio para ficar. Passado o susto, as empresas terão ainda algum tempo para se adaptar a esse novo cenário. Como, no Brasil, o acesso à tecnologia ainda é bem limitado, o comércio tradicional de CDs está garantido por mais alguns anos. 0 problema é que justamente a parcela mais pobre de consumidores é que compra os grandes sucessos populares, que por sua vez são os mais "piratead os". Medidas de controle e repressão ainda funcionarão para resguardar a lucratividade dessas empresas. Mas elas que se preparem, como algumas já estão fazendo, para a nova dinâmica nesse mercado. Senão, o risco é que muitas acabem esquecidas no fundo de algum depósito, vel has, obsoletas e inúteis como um $C D$ daqui a 30 anos.

Adriana Baggio

Colunista do Digestivo Cultural

E-mail: adritulio@hotmail.com 